

\title{
Penerapan Model Pembelajaran Berbasis Proyek dengan Media Real Lab dan Virtual Lab untuk Meningkatkan Hasil Belajar dan Kemampuan Berpikir Kreatif Siswa dalam Materi Titrasi Asam Basa
}

\author{
Siti Rohana Siregar ${ }^{a, *}$, Ani Sutiani ${ }^{a}$, Jamalum Purba ${ }^{a}$ \\ ${ }^{a}$ Program Studi Pendidikan Kimia, Universitas Negeri Medan, Medan \\ *Alamat Korespondensi: asr.sutiani@gmail.com
}

\begin{abstract}
:
This study aims to determine the differences in chemistry learning outcomes and students' creative thinking abilities, as well as the correlation between the two students who are taught using the PjBL learning model using Real Lab media and Virtual Lab. While students' creative thinking skills use observation sheets. The data obtained from the results of the study, namely: (1) To test the hypothesis of student learning outcomes obtained tcount $=2.15$ while ttable $=1.998$ (2) To test the hypothesis of creative thinking abilities students obtained tcount $=3.40$ while ttable $=1.998$ (3) To test the correlation of creative thinking abilities on student learning outcomes obtained rtable $=0.339$ while $r 1=0.391$ and $r 2=0.403$ with contributions of $=15.26 \%$ and $16.27 \%$ in each class, the rest is influenced by other variables. So that the conclusion is drawn that there is a difference between learning outcomes and students 'creative thinking abilities that are learned using PjBL learning models by using Real Lab media and Virtual Lab media. There is a positive and significant correlation between students' creative thinking abilities and student learning outcomes in each experimental class.
\end{abstract}

Key words:

Project Based Learning Model, Real Lab Media, Virtual Lab Media, Students Creative Thinking Abilities, Learning Outcomes

\section{PENDAHULUAN}

Belajar dalam pendidikan dipandang sebagai usaha sadar dan disengaja yang dirancang dengan baik untuk mencapai tujuan pendidikan. Dalam sebuah proses pembelajaran, siswa seharusnya didorong untuk mengembangkan kemampuan berpikir. Oleh karena itu, program pendidikan yang dikembangkan perlu menekankan pada pengembangan kemampuan berpikir logis, analitis, sistematis, kritis, dan kreatif yang harus dimiliki siswa. Berpikir kreatif dapat ditumbuhkembangkan melalui perancangan suatu pembelajaran yang menekankan pada pengeksplorasian kemampuan siswa. Karena pada dasarnya, masing-masing siswa mempunyai potensi kreatif yang berbeda sehingga dalam memecahkan masalah siswa diberi kesempatan untuk menyelesaikan dengan caranya sendiri sehingga dapat menghasilkan gagasan-gagasan yang baru (Prasetyo, 2014).

Salah satu alternatif yang dipandang mampu meningkatkan hasil belajar dan keterampilan berpikir kreatif siswa, yang imbangi dengan adanya pemahaman konsep dan mampu bekerja secara aktif serta kolaboratif dalam pembelajaran kimia adalah 
pembelajaran berbasis proyek atau disebut dengan model pembelajaran Project Based Learning (Sastrika, 2013). Model pembelajaran berbasis proyek merupakan model pembelajaran yang berpusat pada siswa dan menggunakan prinsip learning by doing, yaitu suatu model pembelajaran yang membuat siswa dapat memahami konsep dengan bereksperimen langsung dan menekankan pada penugasan proyek, sehingga diharapkan mampu menjadi model pembelajaran yang tepat untuk meningkatkan karakter siswa dalam berpikir (Winarti, 2014). Oleh karena itu, pembelajaran kimia idealnya dilaksanakan sesuai hakikat sains yang menekankan pada proses mengamati, mengklasifikasi, mengukur, menyimpulkan, meramalkan dan mengkomunikasikan agar siswa berperan aktif dalam pembelajaran dan membangun pengetahuannya sendiri dalam mencari pemecahan dari suatu masalah. Produknya berupa pemahaman mengenai konsep, prinsip, dan teori-teori dasar kimia, sehingga siswa dapat mengaplikasikannya pada hal yang lebih kompleks (Devi, dkk, 2014).

Materi titrasi asam dan basa sebagai bagian dari materi dalam pelajaran kimia kelas XI merupakan satu materi yang menekankan pemahaman konsep pada siswa melalui pengamatan dan juga pengalaman yang dilakukan melalui kerja aktif dan kreatif dalam penyelesaian suatu masalah untuk menarik suatu kesimpulan. Materi ini, memiliki karakteristik yang membutuhkan praktek langsung agar lebih mudah dipahami, sehingga pembelajaran diarahkan pada proses experimental learning yakni pembelajaran dengan berdasarkan pada pengalaman konkret para siswa, diskusi dengan teman yang selanjutnya dapat diperoleh ide dan konsep baru (winarti, 2014).

Pengalaman konkret para siswa akan didapatkan jika proses pembelajaran dilakukan melalui praktikum. Oleh karena itu, dibutuhkan suatu media yang dapat mendukung proses praktikum yang mereka lakukan. Media yang dapat mendukung proses praktikum dalam mengajarkan materi titrasi asam basa tersebut dapat berupa laboratorium real atau laboratorium virtual yang diharapkan mampu meningkatkan kreatifitas siswa dalam menyelesaikan permasalahan yangdihadapi siswa. Laboratorium virtual merupakan suatu media berbasis komputer yang berisi simulasi kegiatan di laboratorium kimia. Laboratorium virtual dibuat untuk menggambarkan reaksireaksi yang mungkin tidak dapat terlihat pada keadaan nyata (Totiana, dkk, 2012). Namun tidak seperti pada laboratorium real, dimana siswa dapat meningkatkan keterampilan psikomotoriknya, misalnya memasang, menggunakan, merakit instrumen praktikum secara langsung. Selain itu dalam laboratorium real, siswa dapat melibatkan semua inderanya yaitu indera penglihatan, pendengaran, perasaan, penciuman, dan peraba dimana hal ini tidak dapat ditemukan pada laboratorium virtual.

Penelitian yang dilakukan oleh Maula (2014) mengenai pengaruh model PjBL terhadap hasil belajar dan kemampuan berpikir kreatif siswa menyimpulkan bahwa penerapan model PjBL memiliki pengaruh yang signifikan terhadap kemampuan berpikir kreatif dan hasil belajar siswa, dengan skor kemampuan berpikir kreatif kelas kontrol 70,25 dan kelas eksperimen 86,17. Sedangkan capaian hasil belajar kognitif kelas kontrol 65,44 dan kelas eksperimen 84,67.

Hasil penelitian Marlinda (2012) mengenai pengaruh model pembelajaran berbasis proyek terhadap kemampuan berpikir kreatif dan kinerja ilmiah siswa menunjukkan, terdapat perbedaan kemampuan berpikir kreatif dan kinerja ilmiah antara kelompok siswa yang belajar dengan MPjBL dan kelompok siswa yang belajar dengan MPK. Dimana penelitian tersebut menyatakan bahwa kelompok siswa yang belajar menggunakan model pembelajaran berbasis proyek (MPjBL) lebih baik kemampuan berpikir kreatifnya daripada kelompok siswa yang belajar dengan model pembelajaran konvensional (MPK).

Beberapa penelitian terdahulu tentang real lab dan virtual lab yang sejalan dengan penelitian ini dilakukan oleh Pambudi (2016) 
yang menyatakan bahwa tidak ada perbedaan prestasi belajar pada materi hidrolisis garam antara siswa yang diberi pembelajaran Learning Cycle $5 E$ menggunakan laboratorium real dan laboratorium virtual. Sedangkan berdasarkan hasil penelitian yang telah dilakukan oleh Lerianti (2014) menyatakan bahwa pembelajaran dengan menggunakan laboratorium virtual lebih baik dibandingkan menggunakan laboratorium real pada materi asam basa.

\section{METODE}

Penelitian ini dilaksanakan di Madrasah Aliyah Negeri 2 Model Medan, Jalan Williem Iskandar, No. VII A, MedanPerjuangan. Penelitian ini dilakukan di MAN 2 Model Medan pada bulan Februari sampai Maret Tahun Pelajaran 2016/2017. Populasi dalam penelitian ini adalah seluruh siswa kelas XI MAN 2 Model MedanTahun Pelajaran 2016/2017 jurusan IPA (Ilmu Pengetahuan Alam) sebanyak 10 kelasyang berjumlah 422 orang. Dalam penelitian ini jumlah sampel yang digunakan adalah 2 kelas dengan menggunakan teknik purposive sampling. Berdasarkan teknik tersebut maka kelas yang digunakan dalam penelitian ini adalah kelas XI IPA 1 yang berjumlah 43 siswa dan kelas XI IPA 7 yang berjumlah 41 siswa. Namun pada kedua kelas tersebut peneliti hanya menggunakan 34 sampel siswa pada masing-masing kelas eksperimen 1 dan kelas eksperimen 2.

Dalam penelitian ini digunakan rancangan RAL (Rancangan Acak Lengkap) yang merupakan perluasan dariPretestPosttestcontrol group design. Perbedaan antara RAL dengan rancangan-rancangan yang lainnya yaitu dalam rancangan acak lengkap, kelompok kontrol tidak wajib ada (Silitonga, 2013). Ada dua kelas yang di teliti dalam penelitian ini, yang di simbolkan dengan X1 untuk kelas pertama sebagai kelas eksperimen 1 dengan perlakuan penerapan pembelajaran berbasis proyek ( $\mathrm{PjBL})$ dengan menggunakan media Real lab dan X2 untuk kelas kedua sebagai kelas eksperimen 2 dengan perlakuan penerapan pembelajaran berbasis proyek $(\mathrm{PjBL})$ dengan menggunakan media Virtual lab.

\section{HASIL DAN PEMBAHASAN}

Data yang diperoleh diolah dengan Microsof Excel untuk uji hipotesis dan begitu juga dengan data hasil observasi yang dilakukan oleh observer.

\section{Hasil belajar kimia siswa yang dibelajarkan dengan model pembelajaran Berbasis Proyek menggunakan media}

Berdasarkan hasil perhitungan diperoleh data statistik hasil belajar siswa pada kelas eksperimen I dan kelas eksperimen II yang dirangkum dalam tabel statistik deskriptif hasil belajar siswa kelas eksperimen I dan kelas eksperimen II pada tabel 1 di bawah ini

Tabel 1. Rangkuman Statistik Deskriptif Hasil Belajar Siswa

\begin{tabular}{|c|c|c|c|}
\hline \multirow[b]{2}{*}{ Data } & \multirow[b]{2}{*}{ Statistik } & \multicolumn{2}{|c|}{ Kelas } \\
\hline & & $\begin{array}{l}\text { Eksperimen I } \\
\text { (Media Real } \\
\text { Lab) }\end{array}$ & $\begin{array}{l}\text { Eksperimen II } \\
\text { (Media Virtual } \\
\text { Lab) }\end{array}$ \\
\hline \multirow{6}{*}{ Pretest } & Rata-rata & 27,50 & 29,71 \\
\hline & $\begin{array}{l}\text { Standar } \\
\text { Deviasi }\end{array}$ & 7,51 & 6,15 \\
\hline & Varians & 56,44 & 37,79 \\
\hline & Minimum & 10,00 & 10,00 \\
\hline & Maksimum & 45,00 & 40,00 \\
\hline & Nilai Total & 935,00 & 1010,00 \\
\hline \multirow{6}{*}{ Posttest } & Rata-rata & 75,88 & 71,03 \\
\hline & $\begin{array}{l}\text { Standar } \\
\text { Deviasi }\end{array}$ & 6,33 & 6,83 \\
\hline & Varians & 40,11 & 46,64 \\
\hline & Minimum & 65,00 & 55,00 \\
\hline & Maksimum & 90,00 & 85,00 \\
\hline & Nilai Total & 2580,00 & 2415,00 \\
\hline
\end{tabular}

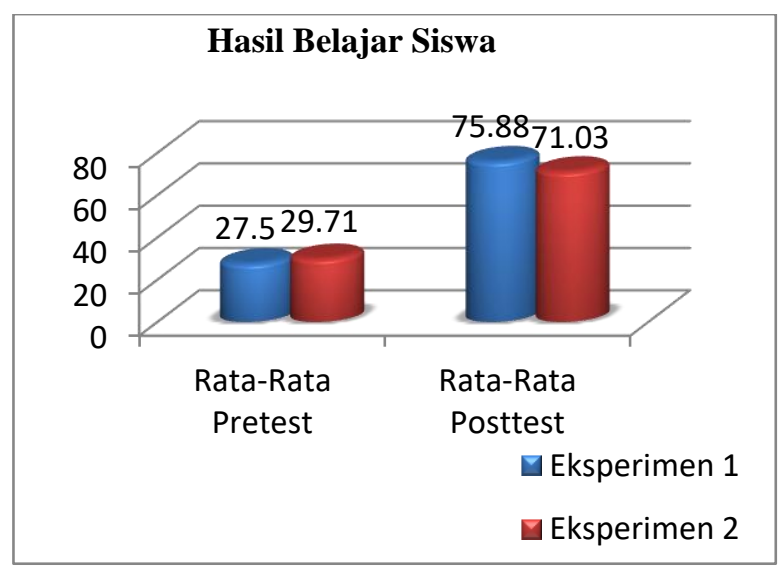

Gambar 1. Diagram Nilai Rata-Rata Hasil Belajar Siswa Kelas Eksperimen I dan Kelas Eksperimen II 
Berdasarkan data hasil belajar siswa pada gambar 1 diatas, pada kelas eksperimen 1 dan kelas eksperimen 2 menunjukkan bahwa rata-rata nilai hasil belajar siswa pada kelas eksperimen 1 lebih tinggi dari kelas eksperimen 2.

\section{Hasil Belajar Kimia Siswa Berdasarkan Kemampuan Berpikir Kreatif Siswa}

Dalam penelitian ini dilakukan pengukuran terhadap kemampuan berpikir kreatif siswa berdasarkan lembar observasi yang diamati oleh observer. Adapun data hasil belajar siswa berdasarkan kemampuan bepikir kreatif siswa pada kedua kelas eksperimen tersebut dapat dilihat pada tabel 2.

Tabel 2. Deskripsi Data Hasil Belajar Berdasarkan Kreatifitas

\begin{tabular}{|c|c|c|c|}
\hline \multirow[b]{2}{*}{ Data } & \multirow[b]{2}{*}{ Statistik } & \multicolumn{2}{|c|}{ Kelas } \\
\hline & & $\begin{array}{c}\text { Eksperimen } \\
\text { I }\end{array}$ & $\begin{array}{c}\text { Eksperimen } \\
\text { II }\end{array}$ \\
\hline \multirow{6}{*}{$\begin{array}{l}\text { Kemampuan } \\
\text { Berpikir } \\
\text { Kreatif Siswa }\end{array}$} & Rata-rata & 70,44 & 59,41 \\
\hline & $\begin{array}{l}\text { Standar } \\
\text { Deviasi }\end{array}$ & 8,11 & 10,78 \\
\hline & Varians & 65,71 & 59,41 \\
\hline & Minimum & 50,00 & 35,00 \\
\hline & Maksimum & 90,00 & 85,00 \\
\hline & Nilai Total & 2395,00 & 2020,00 \\
\hline \multirow{6}{*}{ Posttest } & Rata-rata & 75,88 & 71,03 \\
\hline & $\begin{array}{l}\text { Standar } \\
\text { Deviasi }\end{array}$ & 6,33 & 6,83 \\
\hline & Varians & 40,11 & 46,64 \\
\hline & Minimum & 65,00 & 55,00 \\
\hline & Maksimum & 90,00 & 85,00 \\
\hline & Nilai Total & 2580,00 & 2415,00 \\
\hline
\end{tabular}

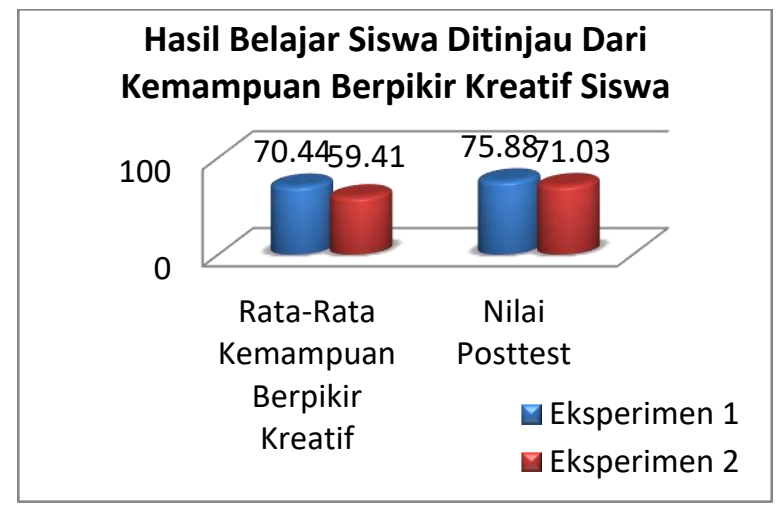

Gambar 2. Diagram Nilai Rata-Rata Kemampuan Berpikir Kreatif Siswa Kelas Eksperimen I dan Kelas Eksperimen II

Berdasarkan data hasil belajar siswa jika ditinjau dari kemampuan berpikir kreatif siswa seperti yang terlihat pada gambar 2 diatas, diketahui bahwa nilai hasil belajar siswa pada kelas eksperimen 1 dan 2 sejalan dengan nilai kemampuan berpikir kreatif siswa pada kedua kelas tersebut. Dimana nilai hasil belajar dan kemampuan berpikir kreatif siswa pada kelas eksperimen 1 lebih tinggi dari nilai hasil belajar dan kemampuan berpikir kreatif siswa pada kelas ekperimen 2 .

\section{Peningkatan Hasil Belajar}

Peningkatan hasil belajar siswa dihitung dengan menggunakan rata-rata gain masing-masing dari kedua kelompok eksperimen menggunakan rumus Gain Ternormalisasi. Berdasarkan perhitungan diperoleh data sebagai berikut:

a. Nilai rata-rata peningkatan hasil belajar kelas ekperimen 1 menggunakan model Project Based Learning (PjBL) menggunakan media Real Lab yaitu sebesar $66,86 \%$.

b. Nilai rata-rata peningkatan hasil belajar kelas ekperimen 2 menggunakan model Project Based Learning (PjBL) menggunakan media Virtual Lab yaitu sebesar 58,88\%.

\section{Uji Hipotesis}

Setelah dilakukan uji prasyarat analisa data, diketahui bahwa data terdistribusi normal serta homogen, selanjutnya dilakukan uji hipotesis dengan menggunakan uji $t$ dua pihak untuk hipotesis I dan II serta korelasi untuk Hipotesis III dengan perhitung manual menggunakan Microsoft Excel.

\section{Pengujian Hipotesis I}

Setelah diketahui bahwa data hasil belajar siswa terdistribusi normal dan homogen maka dapat dilakukan uji hipotesis dengan menggunakan uji statistik uji $t$ dua pihak. Uji ini digunakan untuk mengetahui apakah hipotesis I dalam penelitian ini diterima atau ditolak. Kriteria pengujian menyatakan Hipotesis yang diharapkan (Ha) diterima dan hipotesis nihil atau hipotesis nol (Ho) ditolak jika $-\mathrm{t}_{\text {hitung }}<1 / 2 \alpha \mathrm{t}_{\text {tabel }}$ dan $t_{\text {hitung }}>1 / 2 \alpha t_{\text {tabel. }}$. Dimana Data hasil uji hipotesis tersebut dapat dilihat pada tabel 3 di bawah ini: 
Tabel 3 Hasil Uji Hipotesis I

\begin{tabular}{|c|c|c|c|c|}
\hline \multicolumn{2}{|c|}{ Data Hasil belajar Siswa } & \multirow[t]{2}{*}{$t_{\text {hitung }}$} & \multirow[t]{2}{*}{$\mathrm{t}_{\text {tabel }}$} & \multirow[t]{2}{*}{ Keterangan } \\
\hline $\begin{array}{l}\text { Eksperimen } \\
1\end{array}$ & $\begin{array}{l}\text { Eksperimen } \\
2\end{array}$ & & & \\
\hline $\begin{array}{l}\overline{\bar{X}}=66,86 \\
S^{2}=60,01\end{array}$ & $\begin{array}{l}\bar{X}=58,88 \\
S^{2}=80,18\end{array}$ & 2,99 & 1,998 & $\begin{array}{l}\text { Ha diterima, } \\
\text { Ho ditolak }\end{array}$ \\
\hline
\end{tabular}

Daerah kritis atau daerah penolakan Ho jika $-t_{\text {hitung }}<-1 / 2 \alpha t_{\text {tabel }}$ dan $t_{\text {hitung }}>1 / 2 \alpha$ $\mathrm{t}_{\text {tabel. }}$. Melalui perhitungan interpretasi linier berdasarkan tabel distribusi $t$, diperoleh $\mathbf{t}_{\text {tabel }}=\mathbf{1 , 9 9 8}$ dengan $1 / 2 \alpha=0,025$. Sedangkan berdasarkan perhitungan uji t-test diperoleh $\mathbf{t}_{\text {hitung }}=2,99$. Sehingga $t$ hitung berada di daerah penolakan Ho dengan $-t_{\text {hitung }}<-1,998$ dan thitung $>1,998$. Dengan demikian $\mathrm{Ha}$ diterima, sedangkan Ho ditolak. Hal tersebut, menyatakan bahwa: Ada perbedaan yang signifikan antara hasil belajar siswa pada materi pokok Titrasi Asam Basa dengan penerapan model PjBL menggunakan media Real Lab dengan model PjBL menggunakan media Virtual Lab.

\section{Pengujian Hipotesis II}

Setelah diketahui bahwa data aktivitas siswa terdistribusi normal dan homogen maka dapat dilakukan uji hipotesis dengan menggunakan uji statistik uji t dua pihak. Uji ini untuk mengetahui apakah hipotesis dalam penelitian ini diterima atau ditolak. Kriteria pengujian jika $t_{\text {hitung }}>t_{\text {tabel }}$ maka hipotesis alternatif(Ha) diterima dan hipotesis nihil atau hipotesis nol (Ho) ditolak. Data hasil uji hipotesis dapat dilihat pada tabel 4 berikut:

Tabel 4. Hasil Uji Hipotesis II

\begin{tabular}{|c|c|c|c|c|}
\hline \multicolumn{2}{|c|}{$\begin{array}{c}\text { Data Hasil belajar } \\
\text { Siswa } \\
\end{array}$} & \multirow[t]{2}{*}{$\mathbf{t}_{\text {hitung }}$} & \multirow[t]{2}{*}{$\mathbf{t}_{\text {tabel }}$} & \multirow[t]{2}{*}{ Keterangan } \\
\hline $\begin{array}{l}\text { Eksperimen } \\
1\end{array}$ & $\begin{array}{l}\text { Eksperimen } \\
2\end{array}$ & & & \\
\hline $\begin{array}{l}\overline{\bar{X}}=70,4 \\
\mathrm{~S}^{2}=65,7\end{array}$ & $\begin{array}{l}\bar{X}=59,41 \\
S^{2}=116,3\end{array}$ & 3,40 & 1,998 & $\begin{array}{l}\text { Ha diterima, } \\
\text { Ho ditolak }\end{array}$ \\
\hline
\end{tabular}

Daerah kritis atau daerah penolakan Ho jika $-t_{\text {hitung }}<-1 / 2 \alpha t_{\text {tabel }}$ dan $t_{\text {hitung }}>1 / 2 \alpha t_{\text {tabel }}$. Melalui perhitungan interpretasi linier berdasarkan tabel distribusi $\mathrm{t}$, diperoleh $\mathbf{t}$ tabel $=$ 1,998dengan $1 / 2 \alpha=0,025$. Sedangkan berdasarkan perhitungan uji t-test diperoleh $\mathbf{t}_{\text {hitung }}=\mathbf{3 , 4 0}$. Sehingga $\mathrm{t}$ hitung berada di daerah tolak Ho dengan $-t_{\text {hitung }}<-1,998$ dan $t_{\text {hitung }}>1,998$. Dengan demikian Haditerima, sedangkan Ho ditolak. Hal tersebut, menyatakan bahwa: Ada perbedaan yang signifikan antara kemampuan berpikir kreatif siswa pada materi pokok Titrasi Asam Basa dengan penerapan model PjBL menggunakan media Real Lab dengan model PjBL menggunakan media Virtual Lab.

\section{Pengujian Hipotesis III}

Hipotesis alternatif III adalah apakah terdapatkorelasi yang signifikan antara kemampuan berpikir kreatif siswa dengan hasil belajar siswa yang dibelajarkan dengan model pembelajaran Project Based Learning (PjBL) menggunakan media Real Lab dan apakah terdapat korelasi yang signifikan antara kemampuan berpikir kreatif siswa dengan hasil belajar siswa yang dibelajarkan dengan model pembelajaran Project Based Learning (PjBL) menggunakan media Virtual $L a b$. Pengujian dilakukan menggunakan uji signifikansi korelasi sederhana yang dilakukan dengan membandingkan nilai $r$ yang diperoleh ( $r_{\text {hitung }}$ ) dengan $r_{\text {tabel }}$ pada tingkat signifikansi tertentu, dengan kriteria : jika $r_{\text {hitung }} \geq \mathrm{r}_{\text {tabel }}$ maka Ha diterima dan Ho ditolah. Hasil analisis uji hipotesis III ini dapat dilihat pada tabel 5 sebagai berikut:

Tabel 5. Hasil Uji Hipotesis III

\begin{tabular}{|c|c|c|c|c|}
\hline Kelas & $\mathbf{r}_{\text {hitung }}$ & $\mathbf{r}_{\text {tabel }}$ & $\begin{array}{l}\text { Koefisien } \\
\text { Determinasi } \\
\text { (CD) } \%\end{array}$ & Keterangan \\
\hline $\begin{array}{l}\text { Eksperimen } \\
1 \\
\text { Eksperimen } \\
2\end{array}$ & 0,3906 & 0,339 & $\begin{array}{l}15,259 \\
16,267\end{array}$ & $\begin{array}{l}\text { Berkorelasi } \\
\text { Rendah } \\
\text { Berkorelasi } \\
\text { Cukup }\end{array}$ \\
\hline
\end{tabular}

Dari tabel 5 diatas dapat dilihat bahwa

$r_{\text {hitung }} \geq r_{\text {tabel }} \quad$ dengan $\quad 0,3906 \geq 0,339$ (Eksperimen 1) kemudian 0,4033 $\geq 0,339$ (eksperimen 2), sehingga dapat disimpulkan bahwa Ho ditolak yang berarti : ada korelasi positif dan signifikan antara kemampuan berpikir kreatif siswa dengan hasil belajar siswa yang dibelajarkan dengan model pembelajaran Project Based Learning (PjBL) menggunakan media Real Lab dan ada korelasi positif dan signifikan antara kemampuan berpikir kreatif siswa dengan hasil belajar siswa yang dibelajarkan dengan model pembelajaran Project Based Learning (PjBL) menggunakan media Virtual Lab. 
Selain itu, dapat diketahui bahwa kontribusi penggunaan model pembelajaran $\mathrm{PjBL}$ disertai mediaVirtual Lab terhadap kemampuan berpikir kreatif siswa adalah sebesar $\quad 16,27 \%$ sedangkan $83,73 \%$ disebabkan oleh faktor-faktor lainnya.

\section{KESIMPULAN}

Berdasarkan data hasil penelitian, maka dapat diperoleh beberapa kesimpulan, yaitu sebagai berikut:

1. Terdapat perbedaan yang signifikan antara hasil belajar siswa yang diajarkan menggunakan model pembelajaran Project Based Learning menggunakan media Real $L a b$ dengan hasil belajar kimia siswa yang dibelajarkan menggunakan model pembelajaran Project Based Learning menggunakanmedia Virtual Lab pada pokok bahasan titrasi asam basa, dimana hasil belajar yang lebih baik berdasarkan uji Tukey (uji t) adalah media Real Lab > media Virtual Lab dengan perbandingan nilai rata-rata75,88 $>71,03$.

2. Terdapat perbedaan yang signifikan antara kemampuan berpikir kreatif siswa yang diajarkan menggunakan model pembelajaran Project Based Learning menggunakan media Real Labdengan kemampuan berpikir kreatif siswa yang dibelajarkan menggunakan model pembelajaran Project Based Learning menggunakan media Virtual Lab pada pokok bahasan titrasi asam basa, dimana nilai rata-rata dari kemampuan berpikir kreatif siswa pada kelas ekperimen 1 lebih besar dari kelas eksperimen 2 (70,44 > 59,41), sehingga media Real Lab memberikan pengaruh lebih besar dalam meningkatkan kemampuan berpikir kreatif siswa dibandingkan media Virtual Lab.

3. Terdapat korelasi positif dan signifikan antara kemampuan berpikir kreatif siswa terhadap hasil belajar siswa yang dibelajarkan menggunakan model pembelajaran Project Based Learning dan media Real Lab dengan kontribusi sebesar $15,26 \%$ serta terdapat korelasi positif dan signifikan antara kemampuan berpikir kreatif siswa terhadap hasil belajar siswa yang dibelajarkan menggunakan model pembelajaran Project Based Learning dan media Virtual Lab dengan kontribusi sebesar $16,27 \%$.

\section{DAFTAR PUSTAKA}

Devi, A., dkk. (2014). Perbedaan Implementasi Pembelajaran Kimia Model Problem Based Learning (PBL) Materi Stoikiometri Kelas X MIA SMA Negeri di Kota Surakarta Tahun Ajaran 2013/2014. Jurnal Pendidikan Kimia, 3(4): 126-135

Lerianti, E. (2014). Perbandingan Hasil Belajar Dengan Menggunakan Laboratorium Nyata Dan Laboratorium Virtual Dalam Materi Asam Basa Kelas XI IPA Sma Nusantara Kota Jambi. Skripsi, FKIP, Universitas Jambi, Jambi.

Marlinda, N. (2012). Pengaruh Model Pembelajaran Berbasis Proyek Terhadap Kemampuan Berpikir Kreatif Dan Kinerja Ilmiah Siswa. Skripsi, Program Pascasarjana, Universitas Pendidikan Ganesha, Bali.

Maula, M. (2014). Pengaruh Model Project Based Learning (PjBL)Terhadap Kemampuan Berpikir Kreatif Dan Hasil Belajar Siswa Pada Materi Pengelolaan Lingkungan. Skripsi, MIPA, Universitas Jember, Jawa Timur.

Prasetyo, P. A. (2016). Kreativitas Guru Mata Pelajaran Pendidikan Agama Islam Di SMP Negeri 1 Sumbergempol. Skripsi, FKIP, IAIN Tulungagung, Jawa Timur.

Sastrika, I., dkk. (2013). Pengaruh Model Pembelajaran Berbasis Proyek Terhadap Pemahaman Konsep Kimia Dan Keterampilan Berpikir Kritis. e-Journal Program Pasca Sarjana Universitas Pendidikan Ganesha, 3(1): 1-6 
Siti Rohana Siregar,Ani Sutiani, Jamalum Purbal

Jurnal Inovasi Pembelajaran Kimia (ournal Of Innovation in Chemistry Education) Volume. 1, No.2, Oktober 2019

Penerapan Modd Pembebjaran Bebbasis Proyek dengan Media Real Labdan Virtud Lab untuk Meningkatkan Hasil Beajar dan Kemampuan Berpikir Kreatif Siswa dalam Materi Titrasi Asam Basa

Silitonga, P.M. (2013). Metodologi Penelitian

Pendidikan, FMIPA, Universitas

Negeri Medan, Medan.

Totiana, F., Susanti, E., dan Redjeki, T. (2012). Efektivitas Model

Pembelajaran Creative Problem Solving (CPS) Yang Dilengkapi Media Pembelajaran Laboratorium Virtual Terhadap Prestasi BelajarSiswa Pada Materi Pokok Koloid Kelas XI IPASemester Genap SMA Negeri 1 KaranganyarTahun Pelajaran 2011/2012. Jurnal Pendidikan Kimia, 1(1): 1-6.

Winarti, T., dan Nurhayati, S. (2014). Pembelajaran Praktikum Berorientasi Proyek Untuk Meningkatkan Keterampilan Proses Sains Dan Pemahaman Konsep. Jurnal Inovasi Pendidikan Kimia, 8(2):1409-1420. 